\title{
Steeds minder kennis?
}

De vraag of de curriculumherzieningen van de opleidingen geneeskunde leiden tot betere artsen wordt gesteld door Williams en Lau in het British Medical Journal (BMJ) van 10 juli 2004. ${ }^{1} \mathrm{Zij}$ betogen dat de invoering van vele nieuwe 'problem based learning' (PBL) curricula, als reactie op de eisen die de UK General Medical Council (GMC) stelt aan toekomstige dokters, meer een gevolg is van overtuigende evangelisatie van onderwijskundigen dan dat deze vernieuwingen zijn gebaseerd op rationele overwegingen. Het nadrukkelijker accent op het leren van allerlei aspecten van de 'goede' dokter zou ten koste gaan van de hoeveelheid kennis die een arts nodig heeft om goed te kunnen functioneren.

Deze opinie van de schrijvers, die benadrukken zelf traditioneel te zijn opgeleid, is in mijn omgeving nadrukkelijk opgemerkt, gezien het feit dat ik binnen een week van verschillende kanten een overdruk van het manuscript ontving.

Of PBL opleidt tot betere dokters is een steeds terugkerende vraag. Norman en Schmidt geven aan dat onderzoek naar de curriculumeffecten van PBL erg lastig is, omdat het onderzoek vrijwel nooit plaats kan vinden in een gecontroleerde situatie. ${ }^{2}$ Zo wordt PBL bijvoorbeeld op verschillende manieren geoperationaliseerd, en dat maakt grote gecontroleerde onderzoeken lastig. Wel kan uit diverse deelonderzoeken geconcludeerd worden dat PBL-studenten niet slechter scoren op kennistoetsen dan traditioneel opgeleide studenten. Verder blijkt dat zowel PBLdocenten als -studenten meer tevreden over hun opleiding zijn. ${ }^{3}$
Bij elke curriculumvernieuwing komt de vraag naar voren wat er mankeert aan het huidige onderwijsprogramma. Immers, de huidige artsen functioneren toch ook goed? Dat is ook zo. Het is echter ook zo dat de studenten die nu opgeleid worden over een kleine tien jaar als zelfstandig arts in de maatschappij zullen moeten functioneren. Een maatschappij die aan een voortdurende verandering onderhevig is. Deze veranderingen hebben gevolgen voor de eisen die aan artsen gesteld zullen worden. Als wij onze curricula niet zouden veranderen dan worden op een gegeven moment geen goede artsen meer afgeleverd. Het is dus maar goed dat we ons de afgelopen tien jaar bijvoorbeeld veel hebben beziggehouden met het 'Raamplan 1994 artsopleiding' en een herziene versie ('Raamplan 2001 artsopleiding') hebben gemaakt. De komende jaren zullen we meer rekening moeten gaan houden met bijvoorbeeld de verschillende rollen van de arts en ontwikkelingen als de taakherschikking. ${ }^{4-5}$ In zijn oratie geeft Gans aan wat dit voor het medisch onderwijs zal betekenen: “... het uitoefenen van de geneeskunde moet zoveel mogelijk gebaseerd zijn op wetenschappelijk onderzoek, maar blijft bovenal een sociale vaardigheid" en "... dat het er in het medisch onderwijs om gaat de student gereedschap te geven om in de praktijk met patiëntproblematiek om te kunnen gaan die hij of zij nog niet eerder is tegengekomen" ${ }^{6}$ Het is ook duidelijk dat traditionele onderwijsvormen als hoorcolleges en uit het hoofd leren (stampen) niet de geschiktste vormen zijn om deze nieuwe, niet-kennisgerichte leerdoe- 
len te bereiken. PBL, in welke vorm dan ook, biedt vanuit onderwijskundig oogpunt meer kans op succes.

Dat we curricula voortdurend aanpassen aan de eisen van de tijd wordt gewaardeerd bij onderwijsvisitaties, gezien de opmerking van de visitatiecommissie in 2003 dat de kwaliteitsverschillen tussen de opleidingen kleiner worden. ${ }^{7}$ Wel wijst deze commissie er op dat er geen metingen beschikbaar zijn waarmee de kwaliteit van afgestudeerden beoordeeld kan worden. De redactie wil de lezers van dit tijdschrift dan ook van harte uitnodigen de kwaliteit van de afgestudeerden de komende jaren uitgebreid te onderzoeken en daarover in dit tijdschrift te publiceren.

Het tweede punt waar Williams en Lau zich druk om maken is het kennisniveau van de PBL-studenten. Het niet-voldoende-kennis bezitten is een interessant onderwerp dat niet van de agenda zal verdwijnen. De afgelopen dertig jaar heb ik nooit anders gehoord dan dat de co-assistent van tegenwoordig veel minder weet dan vroeger. Deze meningen zijn meestal gebaseerd op interacties van specialisten met studenten en niet op een objectieve meting. Dat was vroeger zo en dat is nu nog zo, en het zal in Engeland ook wel zo zijn. Het oorzakelijke verband wordt voornamelijk bij de opleiding gelegd. Soms wordt daarnaast ook een verband gezien met maatschappelijke ontwikkelingen. Een voorbeeld hiervan is de mening van een hoogleraar in de chirurgie aan de Rijksuniversiteit te Utrecht. ${ }^{8}$ In zijn afscheidsrede in 1970 keerde hij zich tegen de, in die tijd voorgestelde en ingevoerde, verkorting van het co-assistentschap, omdat “... in die periode van de studie door contact met ervaren artsen het gebrek aan kennis nog tijdig kan worden onderkend en opgeheven." Echt interessant is dat hij als oorzaak van de slechte stu- dieresultaten binnen de faculteit het studentenhuwelijk noemt. Hij zei daar bewijzen voor te kunnen aandragen, maar deed dat niet. Zouden we over dertig jaar ook gaan gniffelen over het artikel van Williams en Lau?

Resteert het probleem dat velen het gevoel hebben dat studenten geneeskunde steeds minder weten, dat PBL-studenten minder weten dan traditioneel opgeleiden en dat Nederlandse studenten dus minder weten dan hun Vlaamse collega's. Maar is dat echt zo?

We hebben een instrument waarmee we dat zouden kunnen meten: de interfacultaire voortgangstoets. Deze toets wordt vier keer per jaar, op hetzelfde moment, voorgelegd aan de studenten geneeskunde van Maastricht, Nijmegen, Groningen en Leiden. Wordt het niet de hoogste tijd dat de overige Nederlandse en de Vlaamse faculteiten hieraan mee gaan doen? Kunnen we eindelijk concluderen dat de verschillen in kennis wel bijzonder klein zijn. Of juist niet. Maar dat is dan weer een goede stimulans voor een curriculumherziening.

\section{Janke Cohen-Schotanus}

\section{Literatuur}

1. Williams G, Lau A. Reform of undergraduate medical teaching in the United Kingdom: a triumph of evangelism over common sense. BMJ 2004;329:92-4.

2. Norman GR, Schmidt HG. Effectiveness of problem-based learning curricula: theory, practice and paper darts. Med Educ 2000;34:721-8.

3. Norman GR. Research in medical education: three decades of progress. BMJ 2002;324:1560-2.

4. Metz JCM, Verbeek-Weel AMM, Huisjes JH, editors. Raamplan 2001 artsopleiding: bijgestelde eindtermen van de artsopleiding. Nijmegen: Mediagroep; 2001

5. LeGrand-van de Boogaard MJM, Rooijen APN van, editors. De zorg van morgen - flexibiliteit en samenhang. Rapport van de Commissie Implementatie Opleidingscontinuüm en Taakherschikking. Den Haag: Ministerie van VWS; juli 2003. 
6. Gans ROB. Geneeskunde en geneeskunst: één werkelijkheid. Rede uitgesproken bij de aanvaarding van het ambt van hoogleraar in de Algemene Interne Geneeskunde aan de Rijksuniversiteit te Groningen op dinsdag 23 januari 2001. Groningen: Rijksuniversiteit Groningen; 2001.

7. Onderwijsvisitatie geneeskunde. Utrecht: Stichting Quality Assurance Netherlands Universities (QANU); 2004.

8. Knipselkrant BOOG. Mededeling in het Nederlands Tijdschrift voor Geneeskunde 1970. 